\title{
Michael Farquhar
}

\author{
SAUDI PETRODOLLARS, SPIRITUAL CAPITAL, \\ AND THE ISLAMIC UNIVERSITY OF MEDINA: \\ A WAHHABI MISSIONARY PROJECT \\ IN TRANSNATIONAL PERSPEGTIVE
}

\begin{abstract}
While the idea that Saudi Arabia has functioned as a beacon of ultraconservative religious influence since the 1970s oil boom is commonplace, the modalities of this influence have rarely been seriously interrogated. As a window onto this issue, this article considers the history of the Islamic University of Medina, an influential Wahhabi missionary project with global ambitions. It pays particular attention to the role played by non-Saudi staff, who for long periods made up a majority of the university's faculty. Previous accounts of migrants working in Saudi religious educational institutions have tended to focus on the contested question of their contribution to the rise of politically activist modes of Islamism within the kingdom. In contrast, the account offered here draws on the concept of spiritual capital to argue that they also played an important part in legitimizing the expansion of the Wahhabi mission to diverse Muslim communities around the world.
\end{abstract}

In 1960 Abu al-A'la Mawdudi, head of the South Asian Islamist movement, the Jamaat-i Islami, arrived in Riyadh carrying plans, apparently drawn up at the request of King

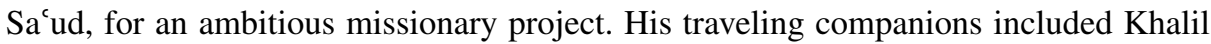
Ahmad al-Hamidi, the Jamaat's point man for relations with Islamic movements in the Arabic-speaking world. Sa ${ }^{c} u d$ convened a committee to discuss the proposals which, besides Mawdudi, included the kingdom's grand mufti Muhammad ibn Ibrahim; the Medina-born Muhammad 'Ali al-Harakan, who would later head the Muslim World League; the Indian scholar Abu al-Hasan 'Ali Nadwi of the Nadwat al-'Ulama' movement; and one 'Abd al-Latif ibn Ibrahim, probably the brother of the grand mufti who was charged with overseeing a system of religious colleges established in Saudi Arabia since the early 1950s. The committee apparently approved Mawdudi's proposals with only minor amendments. Having performed 'umra, Mawdudi journeyed on to Medina, where he visited the site at Wadi al-'Aqiq that had already been earmarked as the location for the Islamic University of Medina (IUM). ${ }^{1}$

Michael Farquhar is a Leverhulme Early Career Fellow in the Department of Politics and International Studies, School of Oriental and African Studies, University of London, London, UK; e-mail: m.farquhar@soas.ac.uk

(C) Cambridge University Press 2015 0020-7438/15 
Since opening its doors in 1961, the IUM has been a central pillar of efforts by Saudi actors to promote the global proliferation of Salafi understandings of Islam, broadly aligned in core matters of creed and praxis with Wahhabism as practiced in the kingdom. The IUM was from the start committed to recruiting over 80 percent of its all-male student body from outside Saudi Arabia, with a comprehensive state-funded scholarship program covering their travel, living costs, tuition, and other expenses. The hope was that after several years of religious studies, they would return to their home communities or settle elsewhere to promote the particular conception of orthodoxy they had learned in Medina. By around 2001, tens of thousands of non-Saudis had been offered scholarships to study at the IUM and nearly 11,600 had secured undergraduate qualifications from its constituent colleges. ${ }^{2}$ However, as the meeting described above suggests, non-Saudis were not only involved as students; they also played a significant part in the founding and running of the project.

While the idea that Saudi Arabia has functioned as a beacon of ultraconservative religiosity since the 1970s oil boom is commonplace, there is a dearth of research considering how this dynamic played out. The routine invocation of "petrodollars" as an explanation for the extension of Wahhabi influence only tells part of the story, and in turn raises questions about how exactly material capital figures in the construction of religious authority. Seeking a nondeterministic and nonreductionist account that treats material investment by Saudi actors as one element in complex struggles to define Islamic orthodoxy in far-flung locations, this article suggests understanding the IUM as situated within a transnational religious economy consisting of flows-both within and across national borders - of material capital, spiritual capital, and religious migrants. In doing so, it pays particular attention to transactions in material and symbolic resources between the university and the large numbers of non-Saudi migrants who joined its faculty.

It is well known that in the second half of the $20^{\text {th }}$ century the Saudi education system, lacking access to an appropriately skilled domestic workforce, relied heavily on nonSaudi staff. However, to the extent that the significance of this migrant workforce has been addressed in academic debate, the focus has been on the contested question of the role played by foreign educators in the emergence and evolution of politically engaged Islamist currents within the kingdom. Drawing on primary sources including university documents and biography collections, along with interviews in Saudi Arabia, Egypt, and the United Kingdom, I argue that migrant staff did not arrive at the IUM only as units of skilled labor or as Islamist ideologues. They also came as bearers of diversified reserves of spiritual capital, symbolic resources that stood to bolster the university's religious standing with Muslim communities around the world.

This article begins by considering religious authority within the Wahhabi scholarly community at the time of the IUM's founding. It then outlines the involvement of non-Saudi staff at the IUM, sketching the backgrounds from which they came and the pathways that brought them to Medina. Next, I explore how the availability of material resources, the consolidation of bureaucratized modes of education, and the cooptation of religious migrants contributed to legitimizing efforts to expand the Wahhabi mission to new audiences. The final section considers the legacy of these dynamics since the early 1990s, by which time the university had been almost entirely purged of foreign staff. 
SPIRITUAL CAPITAL AND WAHHABI RELIGIOUS AUTHORITY

Judging by local press coverage, plans to establish an Islamic university in Medina to host non-Saudi students appear to have gathered pace from around 1958, a moment in history when Saudi rule faced serious challenges on multiple fronts. In Egypt and across the Middle East, the momentum was very much with various brands of radical republicanism that decried the hereditary privileges of monarchy and whose proponents, particularly Jamal 'Abd al-Nasir, were actively engaged in efforts to destabilize the Riyadh regime. Moreover, within the kingdom itself the ruling family was fractured by the competing claims of $\mathrm{Sa}^{\mathrm{c}} \mathrm{ud}$, his brother Faysal, and a faction of more junior princes. ${ }^{3}$ In this context, it seems clear that much of the impetus behind the IUM was political. The new missionary initiative aimed to counter the transnational extension of leftist republican projects by advancing a competing program grounded in claims to historical and religious authenticity. Insofar as it represented an award to the Wahhabi religious establishment, it also stood to bolster patronage relations between dynastic actors and this key constituency. Finally, it would give concrete expression to narratives of national and dynastic legitimacy-grounded in the tropes of kingly munificence, pious leadership, enlightened religious mission, and guardianship of the Holy Cities-for consumption by domestic audiences. ${ }^{4}$

This moment also saw a relative opening up of a Wahhabi scholarly establishment that-notwithstanding enduring internal debates over how to deal with non-Muslims and non-Wahhabi Muslims_-had historically been decidedly exclusivist. ${ }^{5}$ A certain amount of change in this regard had begun to occur gradually from the 1920s, as the Saudi-Wahhabi alliance won the political backing of high profile figures abroad such as the Cairo-based Syrian reformist Muhammad Rashid Rida. ${ }^{6}$ Occurring around the same time, the 1929 suppression by King 'Abd al-'Aziz of the exclusivist Ikhwan militias that had previously served his cause consolidated the standing of those sections of the Wahhabi establishment displaying relatively pragmatic attitudes in regard to dealings with non-Wahhabi Muslims. ${ }^{7}$ By the 1950 s, the Wahhabi establishment was formally headed by Muhammad ibn Ibrahim Al al-Shaykh who, as grand mufti, was prepared to reach out to religious dignitaries from beyond the Arabian Peninsula. $^{8}$

However, despite this gradual process of bridge-building, the Saudi religious establishment at the time was arguably ill equipped to engage in an ambitious effort to extend its authority and influence to Muslim communities around the world. Evaluations of the capacity and standing of the Wahhabi scholarly community in the mid-20th century vary. In a work published in the first half of the 1960s, Hafiz Wahba-an Egyptian who had been employed by the Saudi state for several decades-gave a scathing account:

Very few of the Arabian Ulema have a complete knowledge of the Arabic language and its literature, of rhetoric, etymology, or elocution, and not one of them knows Moslem history properly. Historical knowledge is limited to the Life of the Prophet, and the Caliphs to the end of the Abbasides Dynasty, and, in ancient history, to Tabari and Ibn Alathir ... Since the deaths of Sheikh Abdulla Ibn Abdul Latif and Sheikh Said Ibn Atik, Nejd has had almost no Alam who is really thoroughly versed either in the Haddith or in Moslem Jurisprudence. With the death of Hamad Ibn Faris, Nejd lost a great authority on the Arabic language. ${ }^{9}$ 
Wahba's comments merit attention insofar as they reflect the perspective of an outsider who was at the same time well acquainted with the kingdom and had cordial relations with senior Wahhabi scholars. That said, he was no religious specialist and his limited knowledge of the matters at stake is reflected in the fact that he appears to err even in naming one of the scholars he mentions. ${ }^{10}$ In fact, after the deaths between 1920 and 1930 of those listed by Wahba, Najd did still boast individuals of considerable learning. Some, such as 'Umar ibn Salim, Sulayman ibn Sihman, and 'Abd al-Rahman al-Sa'di would pass away in the decades that followed. However, others-such as Muhammad ibn Ibrahim and a younger generation including the future grand mufti 'Abd al-'Aziz ibn Baz-remained active when the IUM opened its doors. All the same, while such figures were certainly equipped to hold sway within the Najdi context, there is reason to doubt that the bases of their standing could alone have provided for the extension of this authority beyond the Wahhabi fold.

Religious authority within the Wahhabi establishment at the time-and the ways in which this authority came to be remade and extended over the decades that followedmay be usefully understood with reference to the notion of spiritual capital, proposed by Bradford Verter as the basis of a model which "treats religious knowledge, competencies, and preferences as positional goods within a competitive symbolic economy."11 Spiritual capital may be embodied in the individual believer as a result of education or socialization, in the form of religious knowledge, tastes, and skills; it may be objectified in the form of material items such as religious texts or ritual objects; or it may be institutionalized in corporate structures, which thereby acquire the capacity to authorize religious goods. ${ }^{12}$ It is amassed, invested, and exchanged within the terms of a broader Bourdieusian "economy of practices," which also encompasses overlapping transactions in cultural, material, and social goods. Thus material wealth may pay for the production and purchase of ritual objects, for example, or religious qualifications may open doors to certain forms of paid employment. ${ }^{13}$ At the same time, the value of any given form of spiritual capital as a basis of religious standing is not stable; it may be assessed according to differing "hierarchies of religious value" in disparate subcultural contexts. ${ }^{14}$ Moreover, these "hierarchies of value" are themselves in constant flux, as actors wield whatever authority is at their disposal in struggles to define the worth of particular religious texts, practices, and bodies of knowledge. In this sense, spiritual capital represents both a "medium" of conflict (in that accumulation of such capital increases one's authority to engage in disputation over the definition of correct belief and praxis) and an "object" of conflict (in that the value of any given form of spiritual capital is itself subject to contestation). ${ }^{15}$

While Verter is concerned primarily with understanding dynamics that play out across the variety of subcultural contexts existing within the religious field in any given national sphere, his ideas may be applied to the globe-spanning struggles to define Islamic orthodoxy into which the Wahhabi establishment inserted themselves, involving actors situated across the array of subcultural currents constituting the Islamic tradition. When it came to extending their influence beyond the Wahhabi fold, I argue, the Saudi religious establishment faced the problem not of a lack of spiritual capital per se, but rather of a lack of spiritual capital in forms that might be readily recognized as legitimate and valuable bases of religious authority by diverse Muslim communities around the world. 
At this point, it is necessary to situate Wahhabism in relation to Salafi and, more broadly, Islamic beliefs and praxis. If Islam is understood as a discursive tradition, then Salafism amounts to a subcultural "tradition within a tradition," marked out by a distinctive set of principles and points of reference. ${ }^{16}$ While the label is contested and often vaguely applied, Bernard Haykel has defined contemporary Salafism as characterized by several interconnected features. These include: an emphasis on the purity of the beliefs and praxis of the salaf al-sālih (pious ancestors), often understood to denote members of the Muslim community prior to the death of the jurist Ahmad ibn Hanbal in 855; a distinctive understanding of tawhìd (the unicity of God), which in turn tends to give rise to the view that many traditional Islamic practices constitute shirk (polytheism); a stress on combating perceived unbelief, particularly shirk; an insistence that the Qur'an, the sunna, and "the consensus of the Prophet's companions" are the only legitimate bases of religious authority; an emphasis on purging illegitimate innovations (bidac ${ }^{c}$, sing. bid' $a$ ) understood to have corrupted Islamic belief and praxis; and a conviction that the Qur'an and the sunna are clear in meaning and offer sufficient counsel in all circumstances. ${ }^{17}$

Wahhabism displays all of these features and those who are labelled Wahhabis would typically prefer to think of themselves simply as Salafis. However, Wahhabism has certain additional characteristics that justify treating it as a distinguishable subcultural tradition within the broader Salafi fold..$^{18}$ One of these is the central place given within it to works authored by the 18th-century Najdi reformer Muhammad ibn 'Abd al-Wahhab and certain of his descendants. Another feature of the Wahhabi tradition is a distinctive approach to jurisprudence. In principle, Wahhabism shares with many other modes of Salafism a commitment to rejecting blind emulation (taqlid ) of the rulings of the mainstream Sunni schools of law, in favor of verifying legal rulings by independent reasoning (ijtiha $\bar{a})$ with direct reference to the Qur'an and the sunna. However, in practice the Wahhabi tradition has historically been very closely associated with Hanbali jurisprudence. ${ }^{19}$

If the construction of religious authority in regard to a given audience involves the accumulation of symbolic resources in forms recognized as legitimate and valuable by that audience, then religious mission by its very nature presents challenges. The fact of reaching out to individuals or communities who subscribe to different subcultural traditions or different belief systems altogether ensures that the problem of divergent "hierarchies of religious value" inevitably comes into play. Insofar as the bodies of knowledge and other religious competencies of the Wahhabi scholarly community in the mid-20th century related ultimately to foundational texts such as the Qur'an and the canonical hadith collections, they at least met minimal criteria for recognition as legitimate bases of religious authority in Sunni communities beyond the Peninsula. However, the content of Wahhabi scholarship_particularly in core disciplines such as 'aqìda (creed) and fiqh (jurisprudence) - was in many ways grounded in knowledge, skills, and texts with somewhat more limited traction. In 'aqīda, Wahhabism referred back to a Salafi creedal tradition grounded in a corpus structured around works by Ibn 'Abd al-Wahhab and earlier scholars who had been formative influences on his thinking, such as Ibn Taymiyya and Ibn al-Qayyim. The reach of this Salafi creedal tradition remained relatively limited in comparison with the more pervasive Ash'ari and Maturidi traditions. In law, the Hanbali legal practice characteristic of Wahhabism was also relatively marginal when seen in the perspective of the wider Muslim world. ${ }^{20}$ 
Compared with the Hanafi madhhab, which boasted followers from Western Anatolia to the Indian Subcontinent, or the Shafi ${ }^{c} i$, whose influence stretched from East Africa to Java, primary adherence to the Hanbali jurisprudential tradition was largely restricted to the interior of the Peninsula and some other scattered enclaves.

Beyond the question of the content of their scholarship and the embodied capacities to which this gave rise, it is also significant that the qualifications borne by the Wahhabi establishment circulated within networks which were relatively closed and obscure to the outside world. It is true that, from its earliest days in the lifetime of Ibn 'Abd alWahhab, Wahhabi scholarship had never been hermetically sealed from the world beyond the Peninsula. Ibn 'Abd al-Wahhab himself studied in Medina under the hadith scholar Muhammad Hayya al-Sindi (d. 1750), from the town of Adilpur in what is now Pakistan; and in fact there is credible evidence that this experience played a significant role in catalyzing his shift toward reformist commitments, including criticism of taqli $d$ and many popular religious practices. ${ }^{21}$ Comparable long-distance connections persisted to some extent over the two centuries that followed. After Muhammad 'Ali's troops overran the Saudi capital al-Dir'iyya in 1818 , some Wahhabi scholars were exiled to Egypt, whence they subsequently returned to Najd with experience of study in settings such as al-Azhar. ${ }^{22}$ Later in the 19th century, the Wahhabi establishment built up links with the Ahl-i Hadith Salafi movement in India. ${ }^{23}$ Throughout this period, the Wahhabis also had a certain number of sympathizers scattered among scholarly communities from the Maghrib to Iraq. ${ }^{24}$ There are even some reports of students traveling from beyond the Peninsula to study with Wahhabi scholars in the first half of the 20th century. For example, individuals are said to have made their way from Iraq, Yemen, and the Levant to receive instruction from the young Ibn Baz in the town of al-Kharj near Riyadh. ${ }^{25}$ Nonetheless, the scope of such long-distance connections should not be exaggerated. Moreover, in light of the earlier discussion regarding recognition of capital, it is notable that the scholarly communities involved — such as the Ahl-i Hadith—were often already committed to understandings of Islam grounded in principles, practices, and corpuses that overlapped with the Wahhabi tradition.

Wahhabi religious instruction thus remained relatively parochial in ways that had implications for the kinds of symbolic resources available to the Wahhabi establishment. As in other contexts at the time, certification in Najd took the form of $i j \bar{a} z a$ qualifications issued by an individual scholar to an individual student following a period of instruction in a study circle. ${ }^{26}$ In the early 20 th century, a towering Wahhabi scholar such as Sa ${ }^{\text {c }}$ ibn 'Atiq had been able to boast credentials of this kind accumulated through extensive scholarly relations, encompassing prominent Indian hadith specialists such as Siddiq Hasan Khan and Nadhir Husayn al-Dihlawi, with whom he had studied in Bhopal. ${ }^{27}$ Such symbolic capital, accrued in distant locations from scholars with far-reaching reputations, stood to be widely recognized as a legitimate basis of authority in contexts well beyond the Wahhabi heartlands of Najd. However, Ibn 'Atiq had died several decades before the founding of the IUM and those at the core of the Wahhabi establishment in this period otherwise had limited access to such widely recognized resources. On the whole, they relied on forms of certification that circulated largely among those studying and teaching in local centers of learning in Najd. This parochialism is clear in the biographies of ten individuals listed by the historian Muhammad ibn 'Abd Allah al-Salman as examples of particularly prominent figures teaching in mosque study circles in Riyadh in the first 
half of the 20th century. The majority of these men were bound by kinship as members of the extended $\mathrm{Al}$ al-Shaykh family comprising descendants of Ibn 'Abd al-Wahhab, and many were very closely related as brothers, fathers, sons, uncles, and nephews. All had completed their own studies within the Peninsula, mostly within Najd, and substantial overlap between lists of their respective teachers and students confirms the relative insularity of the circles in which they operated. ${ }^{28}$

In the decades leading up to the founding of the IUM, the Saudi monarchy had already begun a process of securing the services of certain scholarly circles from within the Peninsula that were somewhat more cosmopolitan than the core Wahhabi establishment. These included figures from the Hijaz who had longstanding pilgrimage connections with locations across the Islamic world. They also included individuals from the Najdi town of 'Unayza, which was relatively well connected to locations beyond the Peninsula through trade relations, and whose scholars had historically used these ties to engage with far-reaching networks spanning the Hijaz, the Levant, the Gulf, and South Asia. ${ }^{29}$ Individuals from these backgrounds were, for example, co-opted to head the Saudi state-run education system that began to emerge in the Hijaz in the second half of the 1920 s. ${ }^{30}$ In this way, and also through the hiring of migrants from beyond the Peninsula to teach in Islamic institutes geared toward training domestic cadres, the Saudi state and religious establishment gradually began to secure access to an increasingly diverse array of symbolic resources. It was just such a process, I suggest, which would continue to gather momentum at the IUM.

\section{REACHING ABROAD}

From the time that it opened its doors, the IUM was clearly identifiable as a distinctively Wahhabi project. It was put in the care of doyens of the Wahhabi establishment, with the grand mufti Ibn Ibrahim in principle holding the title of university president. In practice, the IUM's day-to-day workings were overseen by his deputy, Ibn Baz. The latter formally became university president in 1970 and remained in that post for a period of five years, after which the IUM was run by a series of less prominent Saudis. ${ }^{31}$ It was also the case that university syllabuses were constructed around the Salafi conception of tawhìd, the cornerstone of the Wahhabi tradition; and, at least at the time of its founding, fiqh syllabuses were clearly oriented toward the Hanbali madhhab, in line with Wahhabi mores. ${ }^{32}$ In the same instance, other aspects of the university's institutional character came to be diversified in ways arguably bound up with its efforts to legitimize itself as a missionary project with global ambitions. Below the top level of management, non-Saudis from divergent geographical, religious, social, and political backgrounds rapidly became numerically dominant both among its teaching staff and also on its senior Advisory Council.

According to the IUM's founding document, Advisory Council members were to be selected to achieve geographical breadth and a range of expertise, and they were to meet regularly to discuss the university's structure and functioning. ${ }^{33}$ Issues that they considered included syllabuses, amendments to the university statutes, and the establishment of new colleges. ${ }^{34}$ The council included an array of religious luminaries drawn both from within and from far beyond Salafi networks. The first council included just two Saudis, Ibn Baz and 'Abd al-Muhsin al-'Abbad, a young scholar from Zilfi 
who taught at the IUM from the time that it opened and would later take charge of the university for a period following Ibn Baz's departure. ${ }^{35}$ Alongside them sat three prominent scholars and activists from South Asia: Mawdudi and Nadwi, both wellknown non-Salafi figures who had attended the meeting described at the start of this article, and Muhammad Dawud al-Ghaznawi of the Ahl-i Hadith Salafi movement in Pakistan. They were joined by two Egyptians: 'Abd al-Razzaq 'Afifi, who had just quit as head of the Salafi movement Ansar al-Sunna al-Muhammadiyya in Egypt in order to settle in Saudi Arabia; and Hasanayn Muhammad Makhluf, a prominent Azhari and former grand mufti of Egypt. Two Iraqi members were Muhammad Mahmud al-Sawwaf, a senior Muslim Brother who relocated to the kingdom around this time; and Muhammad Bahjat al-Athari, a student of the turn-of-the-century Iraqi Salafi scholar Mahmud Shukri al-Alusi. Syrian members included Muhammad al-Mubarak, a cofounder of the Syrian Muslim Brothers; and Muhammad Bahjat al-Bitar, who came from a prominent line of Salafi scholars in Damascus. Others hailed from Indonesia, Aden, Mauritania, Tunisia, Jordan, and elsewhere. ${ }^{36}$

When it came to the faculty itself, non-Saudi teaching staff were hired mainly from the Middle East and North Africa, presumably in large part because the language of instruction was Arabic. Foreigners were an important presence right from the start, and by the early 1970s staff lists described just eight of thirty-three faculty members as Saudi. Of the remainder, over half were Egyptian nationals while others hailed from Jordan, Syria, Morocco, and Pakistan. ${ }^{37}$ Even out of those listed as Saudi at that time, more than half had acquired Saudi citizenship after relocating to the kingdom from their home communities in countries including Egypt, Mauritania, Algeria, and Mali. A massive expansion of the university in the wake of the 1970s oil boom led to a further influx of migrant staff members. By the early 1980s, university documents classed as Saudi less than two-fifths of its faculty members-who in total now numbered nearly 400 individuals - and, again, it is clear that even this category included scholars born outside the kingdom who had since settled there. Non-Saudi faculty at this time included over 130 Egyptians, as well as dozens of Sudanese and lesser numbers from Syria, Jordan, Iraq, India, Pakistan, Morocco, Palestine, South Yemen, Mauritania, and even Australia. ${ }^{38}$

Far from being absorbed anonymously into low-ranking positions, these migrants occupied highly visible posts within the university framework. The Syrian Muslim Brother Muhammad al-Majdhub, for example, spent fifteen years as a member of the editorial board of the university journal, a publication that included contributions from countless non-Saudi staff and bore the stamp of foreign social movements whose members were involved in the IUM project. ${ }^{39}$ A program for monitoring student life and organizing activities outside of class was headed for more than a decade from the mid-1970s by the Egyptian Muslim Brother al-Sayyid Nazili. ${ }^{40}$ Non-Saudis and naturalized citizens were represented on the University Council, a body that oversaw operational matters. They also sat on the councils of the university's constituent colleges, and served as heads of departments within colleges.

The migrations that helped to shape this diverse faculty - and that were in turn shaped and sustained by the IUM's existence-followed a host of trajectories. A proportion of those scholars from beyond the kingdom who became involved in the IUM stayed for a limited period before returning to their countries of origin. For some of these sojourners, 
including Advisory Council members who had no other long-term business in Saudi Arabia, visits to Medina might simply have been long enough to attend a meeting. For others, the stay could be very lengthy. The leading Ahl-i Hadith scholar 'Abd al-Ghaffar Hasan recalled that after being hired by an IUM staff member who had traveled to his house in Pakistan in the mid-1960s, he had hoped to spend the rest of his life in Medina. In the event, he taught hadith studies there for sixteen years before returning to Pakistan and taking up a position on the official Islamic Ideological Council charged with advising the government on matters of sharic $a .{ }^{41}$ Particularly as the university expanded and its teaching body grew, a great many staff likely fell into the sojourners category, often recruited on a temporary basis from institutions such as al-Azhar. ${ }^{42}$ Their journeys were facilitated in part by IUM deputations that traveled abroad-including to Egypt, Syria, Lebanon, Jordan, and Pakistan—specifically with a view to contracting new employees. ${ }^{43}$

The faculty also included individuals who either had already settled permanently in Saudi Arabia prior to the founding of the IUM or would do so after taking up employment there. These immigrants remained in the kingdom for the duration of their lives, frequently becoming naturalized citizens, starting families, and integrating into the new cultural, religious, and social milieu in which they found themselves. One such figure was 'Abd al-Fattah al-Qari', born around 1911 in Kokand, in the Fergana Valley in what is now Uzbekistan. He had relocated to the Hijaz as a young man, and had studied and taught in various religious educational institutions in Mecca and Riyadh before taking up a post teaching Qur'an and Qur'anic recitation at the IUM from the time of its establishment. ${ }^{44}$ His son, 'Abd al-'Aziz al-Qari', would go on to study at the IUM before himself becoming a longstanding member of its faculty, serving as dean of its College of the Qur'an and Islamic Studies in the early 1980s. ${ }^{45}$

For a final category of migrants, a stint in Medina represented just one stage on long and convoluted cross-border pathways. This kind of itinerant trajectory is illustrated in the biography of the Moroccan reformist scholar Taqi al-Din al-Hilali, who was invited by Ibn Baz to join the IUM faculty in 1968. By this time in his life, al-Hilali had spent periods studying and teaching not only in his native Morocco but also in the Saudioccupied Hijaz in the 1920s, and in Algeria, Egypt, India, Iraq, and Germany. During these peregrinations, he had made contact with Rashid Rida in Cairo, taught Arabic literature and studied English at the Dar al- 'Ulum college run by the Nadwat al- 'Ulama' in Lucknow, earned a doctorate from the University of Berlin, and been arrested by the Spanish colonial authorities in northern Morocco over his links to the Egyptian Muslim Brothers. ${ }^{46}$

The migrations that converged on the IUM campus were sometimes channelled through longstanding pilgrimage and educational circuits. Many of those who would become leading figures at the university had in this way turned up independently on the Saudis' doorstep in the decades prior to the IUM's founding. 'Umar ibn Muhammad Fallata, who headed an IUM-affiliated school in Medina known as Dar al-Hadith before serving as university secretary general from 1978 until 1983, had himself been born just as his parents were approaching Mecca at the end of a long passage from Nigeria in the 1920s. This journey in turn built on pilgrimage links to the Hijaz dating back to his grandfather. ${ }^{47} \mathrm{He}$ and many other migrants came into contact with one another and with Wahhabi scholars through local educational networks in Najd and the Hijaz, 
teaching and studying together in sites including mosques, private schools, and a new set of religious colleges overseen by the Wahhabi establishment in Riyadh from the early 1950s. The forging of such connections is seen in the trajectory of another high-profile IUM staff member, Muhammad al-Mukhtar al-Shinqiti, who arrived in the Hijaz as a pilgrim in 1939 having apparently traveled most of the 5,000-kilometer journey from his native Mauritania on foot. Before taking up a teaching post at the newly opened IUM, where he would remain until the early 1980s, he studied with scholars in Mecca and Medina, and taught in the Prophet's Mosque in Medina, a private school in Jidda, and a state-run religious institute in Riyadh. ${ }^{48}$

Apart from pilgrimage routes, exile politics also played a part in driving migrations to Medina. The experience of Muslim Brothers seeking refuge in Saudi Arabia from persecution in countries across the region is particularly well known. Crackdowns on Muslim Brothers in Egypt in 1954 and again in the mid-1960s-followed by the release of many members of the organization from jail under Anwar al-Sadat in 1971 —and periods of concerted repression in Syria and Iraq from the late 1950s onwards contributed to pushing large numbers of Brothers into employment in the Saudi education system and wider economy. ${ }^{49}$ The biographies of many of those who took up roles at the IUM-either as part of its teaching faculty or as members of its Advisory Councilcohere with this broad pattern. ${ }^{50}$ However, the role of exile politics in this regard did not start and end with the crackdowns on the Brothers; similar dynamics also occurred earlier as a result of colonial repression. The prominent IUM staff member Hammad al-Ansari, for example, had originally been compelled to flee the French Sudanwhich would later become Mali- to the Hijaz as a result of pressure exercised by the colonial authorities there during World War II. ${ }^{51}$ Similarly, the aforementioned 'Umar Fallata was himself a devoted student of 'Abd al-Rahman al-Ifriqi, another scholar from the French Sudan who had settled in the Hijaz after apparently fleeing a run-in with the colonial authorities. Al-Ifriqi, who was viewed by the French as a key expatriate leader of anticolonial contention, ${ }^{52}$ ran the Medina Dar al-Hadith until his death in 1957, after which time it was taken over by Fallata and then in 1964 absorbed into the IUM..$^{53}$

Besides Muslim Brothers, the university faculty came to include individuals associated with a variety of other social movements, particularly the South Asian Ahl-i Hadith and the Egyptian Salafi movement Ansar al-Sunna al-Muhammadiyya. Established in Egypt in 1926, Ansar al-Sunna already had a longstanding relationship with the Saudi religious and political establishments by the time the IUM emerged. Its founder Muhammad Hamid al-Fiqi had settled in the Hijaz in the 1920s and forged close relations with the Saudi political establishment. As mentioned above, the movement secured an effective presence on the IUM's founding Advisory Council in 'Abd al-Razzaq 'Afifi, an Ansar al-Sunna stalwart who had previously taught in Saudi Arabia and who in around 1960 ended a brief stint as president of the organization in Egypt in order to settle permanently in the kingdom. 'Afifi was subsequently appointed to top religious bodies in Saudi Arabia, including the Council of Senior 'Ulama'. ${ }^{54}$ A number of Egyptian Salafi scholars associated with Ansar al-Sunna also took up teaching positions at the IUM. ${ }^{55}$ The movement's members, whose creed was considered sound by the Wahhabi establishment, were even trusted with teaching and setting syllabuses on the sensitive subject of tawhīd. ${ }^{56}$ 
As mentioned previously, the South Asian Ahl-i Hadith also had enduring ties to the Wahhabi establishment which went back even further than those of Ansar al-Sunna. In the last quarter of the 19th century, Najdi 'ulama' - including the aforementioned Sa'd ibn 'Atiq — began traveling to Delhi and Bhopal to study with Ahl-i Hadith scholars such as Siddiq Hasan and Nadhir Husayn al-Dihlawi. ${ }^{57}$ It was an Indian Ahl-i Hadith affiliate, Ahmad ibn Muhammad al-Dihlawi, who in the early 1930s founded the Medinan Dar al-Hadith, which would subsequently be taken over by al-Ifriqi and 'Umar Fallata and then folded into the IUM framework. Al-Dihlawi also established a religious school of the same name in Mecca around the same time, in cooperation with an Ansar alSunna-linked Egyptian scholar named 'Abd al-Zahir Abu al-Samh. Just as the Medina Dar al-Hadith had been absorbed by the IUM in 1964, so the Mecca Dar al-Hadith was brought under its administrative umbrella in 1971. ${ }^{58}$ In addition to the appointment of the Ahl-i Hadith's Muhammad Dawud al-Ghaznawi to the IUM's founding Advisory Council, teaching posts at the university were subsequently given to scholars from the movement including Hafiz Muhammad Gondalavi, 'Abd al-Ghaffar Hasan, and 'Abd al-Karim Murad. ${ }^{59}$

For many migrants who arrived in Medina through these diverse routes, a spell at the IUM offered an opportunity to combine employment seen as benefiting the global umma with career advancement and the chance to take advantage of relatively high wages. Egyptians who have worked at Saudi Arabia's Islamic universities emphasize the material remittances made possible by these circular migrations, which could be used to support personal projects such as setting up a home and starting a family, as well as the value associated with spending time in the proximity of the Holy Cities. ${ }^{60}$ Saudi connections also benefited movements whose members were involved at the IUM. On one occasion in the mid-1970s, for example, the university made a donation of 50,000 riyals to the Nadwat al-'Ulama'. ${ }^{61}$ In the few years after the Ahl-i Hadith founded a madrasa known as the Jamica Salafiya in Banaras in 1966, the IUM sent teachers to support the fledgling institution. ${ }^{62}$ According to Muhammad Qasim Zaman, the Banaras Jami a Salafiya also happened to be partially funded by Saudi Arabia and to have been "inaugurated ... by the Saudi ambassador." ${ }^{63}$ In addition, the IUM maintained formal relations with an Ahl-i Hadith madrasa of the same name in Faisalabad, whose students "are regularly sent for higher studies to Saudi Arabia" after which "many return to teach in this and other Ahl-i Hadith madrasas." $"$ The flows of religious migrants that grew up around the IUM were thus bound up with transactions in material capital, which could in turn be put to work in the service of an array of projects, religious and otherwise. As I argue in the following section, these same transactions also involved the exchange and accumulation of symbolic resources.

\section{MIGRATION, BUREAUCRATIZATION, AND LEGITIMIZATION}

Academic debate on the role of foreigners in Saudi Islamic universities such as the IUM has tended to revolve around the part that they are reputed to have played in catalyzing the emergence of the politically engaged domestic Islamist current known as the Sahwa, which peaked in the kingdom in the early 1990s. Some observers have emphasized the influence that Muslim Brothers from Egypt and the Levant, as well as the Syrian former Muslim Brother Muhammad Surur Zayn al- 'Abidin, arguably exerted 
on local activists. ${ }^{65}$ Others have been inclined to downplay the role of migrants in this regard, tending to give weight instead to indigenous traditions and grievances in the crystallization of Sahwi activism. ${ }^{66}$ This debate's focus on the Saudi national sphere, I suggest, has tended to sideline another set of considerations relating to cross-border flows of scholars and educators centered on institutions such as the IUM-that is, the ways in which the co-optation of religious migrants contributed to legitimizing the extension of Wahhabi influence and the authority of the Saudi religious establishment beyond the kingdom's borders.

Even as the IUM absorbed this influx of foreign staff, the content of its teaching remained clearly informed by Wahhabi concerns. Soon after its founding, the IUM's fiqh syllabuses underwent a subtle shift away from their original Hanbali bent toward an approach that was framed as explicitly comparative and encompassing the mainstream Sunni schools of law. ${ }^{67}$ While there is evidence that this development related in part to the presence of migrant staff and recognition of the need to cater to a diverse student body, it also meshed with a broad shift in 20th-century Saudi Arabia away from narrow adherence to Hanbali fiqh; and it was consistent with the emphasis that had always existed within the Wahhabi tradition-in principle, if not always in practice-on the rejection of taqlīd in favor of ijtihād. ${ }^{68}$ At the same time, creed syllabuses in use in the early 1990s remained firmly grounded in the Salafi conception of tawhì that is the bedrock of the Wahhabi tradition. ${ }^{69}$

Juxtaposed with this Wahhabi-oriented program of study, the diversity of accents, appearances, and modes of comportment of the migrants who made up the IUM faculty no doubt gave credence to the university's claims to be a beacon for universal Islamic mission, rather than for a quite distinct subcultural tradition rooted in the very particular social, geographical, and historical context of Najd. On a cosmetic level, at least, this diversity surely helped to dilute the impression of a project operating narrowly in the service of the Wahhabi establishment and the Saudi state. In a more specific sense, however, migrants who taught at the IUM also arrived in Medina as bearers of spiritual capital in a diversity of forms that would be recognized as legitimate bases of religious authority in Muslim communities around the world.

The knowledge and skills brought by migrant staff members provided for core Wahhabi commitments to be built into programs of study that expanded enormously over time to span the gamut of Islamic sciences. The undergraduate syllabus at the time of the university's founding fit on a single page. It outlined one program of study built around eleven subjects, most of which-including tawhìd, figh, hadith studies, Qur'anic exegesis, and grammar-had long been mainstays of Wahhabi scholarship. Moreover, these subjects were taught to a significant extent from texts-including Ibn Qudama's fiqh manual al-Muqni ${ }^{c}$ and the Qur'an commentary of al-Baghawi-that had also long featured in the Wahhabi canon. ${ }^{70}$ By the early 1990 s, undergraduate syllabuses stretched to over 200 pages, albeit including some repetition. While core Wahhabi commitments remained firmly in place, study options by this time had grown to include dozens of disciplines and subdisciplines. These in turn were taught with reference to a vastly expanded array of texts, the latter including many points of overlap with the diverse corpuses that formed the bases of religious learning in other subcultural contexts across the Muslim world. ${ }^{71}$ The presence of works by Azharis and figures associated with movements such as the Muslim Brotherhood, Ansar al-Sunna, and the Ahl-i Hadith is 
evidence that the expansion and diversification of IUM syllabuses were bound up with the involvement of migrant staff.

In addition to embodied skills and knowledge, migrant staff also brought with them qualifications accumulated through engagement with extensive networks of individuals and institutions that far surpassed the scope of the Wahhabi circuits of Najd. Some faculty members had accumulated symbolic resources of this kind entirely through traditional forms of instruction, rooted in study circles with individual scholars. One particularly renowned figure to fit this profile is Muhammad al-Amin al-Shinqiti, who in the 1940s made the epic overland journey from his home in Mauritania to the Hijaz in order to perform the hajj. Besides working at the IUM, he would earn a place at the heart of the Saudi religious establishment, eventually joining the kingdom's Council of Senior 'Ulama'. ${ }^{72} \mathrm{~A}$ former student of his at the IUM recalled that, playing on the fact that the Arabic word for a university or school certificate also refers to the formula by which Muslims avow their faith, al-Shinqiti used to declare, "I have only one shahāda: 'lā ilāha illā Allah." "73 What he also had, however, was an extensive reserve of informal, personalized qualifications accrued over the course of an educational career that spanned studies in rural Mauritania with members of his family, scholars of his tribe and marabouts, as well as the mosque circles of scholars in Mecca and elsewhere in Saudi Arabia. Similarly, his high-profile IUM colleague Jabir Abu Bakr al-Jaza'iriprior to moving to Saudi Arabia in the early 1950s — had studied in his native Algeria

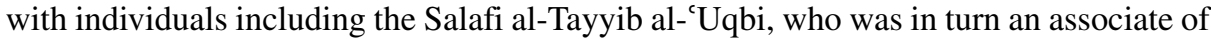
the renowned reformist figurehead Ibn Badis. ${ }^{74}$ Such men thus had scholarly pedigrees that would be recognizable far beyond the Peninsula.

Other migrant staff held forms of certification bestowed by institutions, rather than individuals, across the Middle East and far beyond. Many of those employed at the IUM in the early 1970s held the shahāda 'älamiyya, equivalent to a master's degree, while others had undergraduate and master's degrees or doctorates. Their qualifications covered subject areas including jurisprudence, Qur'anic studies, hadith studies, grammar, literature, and pedagogy. ${ }^{75}$ By the early 1980s, the vast majority of staff had university degrees. ${ }^{76}$ An especially large proportion of them had studied at al-Azhar, its graduates accounting for nearly a third of the more than 130 staff members teaching at the IUM's flagship College of Shari ${ }^{c} a$ at that time. While the Azharis in the College of Shari'a were mostly Egyptians, they also included individuals from Jordan, Sudan, Syria, and Saudi Arabia itself. The deans of the university's five colleges at that stage were all Saudi citizens. However, at least three of them also boasted degrees from al-Azhar. ${ }^{77}$ Significant numbers of staff at the IUM in the early 1980s had also been trained at the Islamic University of Umm Durman in Sudan, an institution with strong historical ties to both al-Azhar and Cairo's Dar al- ${ }^{\text {CUlum. }}{ }^{78}$ Other migrant staff members had studied at universities elsewhere in Egypt, Sudan, Syria, Iraq, Morocco, Libya, Pakistan, and even the United Kingdom. ${ }^{79}$ In some cases, their claims to scholarly authority in this religious context rested in part on qualifications earned outside of what might be readily thought of as the religious educational sphere, indicating how symbolic resources could be put to work across multiple fields. Significant numbers bore degrees earned in broadly secular institutions in Muslim-majority countries, while some were alumni of European institutions such as the Universities of London and Edinburgh. ${ }^{80}$ These diverse forms of certification-from venerable centers of Islamic learning such as 
al-Azhar, as well as younger but nonetheless well-established religious universities and even secular institutions across the Middle East and Europe-were displayed prominently in promotional literature produced by the IUM.

Material investment in the hiring of migrant staff thus provided for the accumulation of the symbolic resources that are a prerequisite for any religious educational institution hoping to authorize a given set of religious goods, to authoritatively critique and thereby delegitimate other kinds of religious goods, and to bestow religious status and authority upon its own students ${ }^{81}$-in short, to engage effectively in struggles to define orthodoxy. Importantly, spiritual capital was brought by migrant staff members in an array of forms, the legitimacy and value of which stood to be readily recognized in the communities far beyond the kingdom which were the intended recipients of the IUM's mission. Diversified reserves of symbolic resources-including ija $z a$ certificates accumulated through far-reaching scholarly networks, and degree certificates from well-known and widely respected institutions - stood to have substantially greater traction in a broader range of contexts than would qualifications accrued in the parochial study circles of Najd.

Of course, there were often significant disparities between the religious traditions within which migrant staff had originally accumulated their own capacities and qualifications, on the one hand, and the Wahhabi-oriented modes of religious instruction that these resources were now being used to legitimize, on the other hand. The very large Azhari contingent, for example, had been trained in an institution that has historically been associated primarily with the Ash'ari creedal tradition and the Hanafi, Shafi ${ }^{\mathrm{i}} \mathrm{i}$, and Maliki schools of law, in contrast with the Salafi creed and distinctive approach to fiqh that defined the IUM. In practice, I suggest, the legitimization of the university rested in part on the capacity to break down, blur, or elide such distinctions. This was a simple matter in the case of staff members who had themselves undergone religious conversions of sorts. In recounting the trajectory of Muhammad al-Amin al-Shinqiti, for example, his IUM colleague and biographer Muhammad al-Majdhub notes that as a young student al-Shinqiti had held reservations about the Wahhabi tradition. However, he then met Saudi scholars in the Haramayn, read works of the Hanbali law school for the first time, and encountered the writings of Ibn Taymiyya and Ibn al-Qayyim. We are told that he consequently underwent a transformation, consciously transcending his Maliki upbringing and dedicating himself to re-studying hadith collections in light of his new understanding of their status as a key source of fiqh derivation. ${ }^{82}$ Through such conversion narratives, the pious devotion, scholarly capacities, and qualifications of a lifetime of study spanning different subcultural contexts could effectively be mobilized to legitimize Wahhabi teachings.

More routinely, such distinctions appear to have been tacitly elided. It was not necessary for foreign scholars and religious functionaries to wholeheartedly accept the validity of Wahhabi doctrine and social norms in order to take up lucrative employment in the Saudi education system; and anyway the teaching of especially controversial subjects at the IUM, particularly tawhi $\bar{d}$, was largely the preserve of Saudis and a small number of foreign Salafis. ${ }^{83}$ It seems likely that a significant proportion of the qualified and skilled migrants whose presence helped to lend credibility to the IUM did not agree with the details of its missionary message in their entirety, particularly in core matters of creed. In the teaching of law, this elision may have been smoothed to some extent 
by the IUM's shift away from the clear primacy given to Hanbali jurisprudence in its original syllabuses. More broadly, it was no doubt facilitated by the increasingly bureaucratized modes of instruction that crystallized there over time. An elaborate, fixed syllabus-including not only curricula specifying required and recommended texts, but also detailed lists of intended learning outcomes-limited the autonomy of individual staff members and allowed the Saudi scholars who headed the institution and its constituent colleges to direct and maintain oversight of teaching.

This bureaucratized system of education-in contrast to the personalized study circles that had historically been the prevailing mode of instruction in the Peninsula-also paved the way for the institutionalization of the diverse symbolic resources brought by migrant staff, such that these could be appropriated and incorporated into the fabric of the university itself. Previous research has considered the relatively straightforward transmission of spiritual capital in objectified forms through gift giving, and the ways in which this may reconfigure social relationships and status. ${ }^{84}$ While the knowledge, qualifications, skills, and other capacities of individual IUM staff members were not material objects to be physically transferred in this sense, it is nonetheless possible to observe specific processes by which these embodied symbolic goods came to form bases of specifically institutional authority.

In the course of time, the IUM cohered as an entity with its own corporate identity, over and above that of the individual persons who taught there. In promotional literature stamped with the university's name and logo — consisting of an archway, a minaret, and an open book radiating the light of correct knowledge - their qualifications could be displayed not only as personal credentials but also as institutional resources. Similarly, written syllabuses could outlive the tenures of the individual staff members in whose knowledge and skills they were grounded. As a consequence of such processes, the university - in ways distinct from the standing of individual scholars-acquired the capacity to authorize the content of its teaching and to issue pro forma certificates of qualification to its students. This folding of individual capacities and qualifications into the ambit of the institution was further promoted through a strategy of absorbing its own graduates back into its faculty. Within years of opening its doors, the IUM began hiring its own alumni to teach in its affiliated secondary- and intermediate-level institutes. ${ }^{85}$ By the early 1980s, over a quarter of those working in its flagship College of Sharica were IUM graduates, almost all of them recruited from among the small proportion of Saudis who had studied there. ${ }^{86}$ Skills and certification acquired at the IUM-in part through the input of migrant staff members-were thus drawn upon as resources to be bestowed by the same institution to the next generation of students.

\section{DOMESTICATING THE IUM}

By the early 1990s, the practice of co-opting foreigners to work at the IUM was coming to an end. At the start of that decade, nearly 90 percent of the 385 members of the IUM's teaching staff were described in university literature as Saudi. Toward the end of that decade, there were no more than a handful of non-Saudi staff left on campus. An authorized history of the IUM frames this development as part of broader, countrywide efforts to "Saudize" the national economy. ${ }^{87}$ The university's history is thus in retrospect narrated in terms of the growing autonomy of a Saudi institution from the 
foreigners whose efforts had made its operation possible in the first place. In a parallel development in the course of the 1990s, the IUM also came increasingly under the sway of adherents of a distinctive strand of Salafism most prominently associated with faculty members Muhammad Aman al-Jami and Rabic ibn Hadi al-Madkhali. This mode of Salafism gives pride of place to the purification of creed and the principle of default obedience to incumbent political authority, and it is distinguished by the stridency of its adherents' attacks on politically engaged Islamists. The Jamiyya or Madkhaliyya, as it is often labeled, came to strongly color the IUM's missionary project from the 1990s, its proponents backed by the regime as a bulwark against Islamist challenges to Saudi dynastic legitimacy. ${ }^{88}$ At the same time as the IUM gained increasing autonomy from migrant actors and resources, its role as an instrument of national state power was thus brought ever more sharply into focus.

Yet recent research has emphasized that the religious current represented in the figures of al-Madkhali and al-Jami itself has diverse roots, for it is tied to the scholarship of the Albania-born former IUM staff member Nasir al-Din al-Albani and the thinking of the South Asian Ahl-i Hadith. ${ }^{89}$ More pertinently, particularly given the argument being made in the present article, the religious authority of its key figureheads is in many cases also grounded in their imbrication in just the kinds of migratory circuits discussed here. Al-Madkhali was one of a minority of Saudis admitted to study at the IUM in its early years. He counted among his teachers not only Saudis such as Ibn Baz and al-'Abbad but also migrant scholars who worked there at the time, including Muhammad al-Amin al-Shinqiti and al-Albani. As Roel Meijer has noted, he derives particular authority from the epithet "carrier of the flag of [knowledge] of jarh wa-ta'dìl [the science of evaluating the validity of a hadith text by evaluating the characters of its transmitters] in this age," bestowed upon him by al-Albani. ${ }^{90}$

The role of such cross-border transactions in bolstering the religious standing of the figureheads of this current comes through more clearly still in the biography of al-Jami. Born in eastern Ethiopia in the early 1930s and educated in the Shafi ${ }^{\circ} i$ environment of his village and nearby settlements, al-Jami made the journey to Saudi Arabia via Somalia and Yemen in time for the hajj season of 1950 . Once there, he studied not only with Najdi scholars such as Ibn Baz and Ibn Ibrahim but also with an array of migrants, including the aforementioned West Africans Muhammad al-Amin al-Shinqiti, 'Abd al-Rahman al-Ifriqi, and Hammad al-Ansari, the Egyptian Ansar al-Sunna scholars 'Abd al-Razzaq 'Afifi and Muhammad Khalil Harras, and the Egyptian Salafi 'Abd al-Razzaq Hamza. He would subsequently earn a master's degree from the University of Punjab and a doctorate from Cairo's Dar al-'Ulum. ${ }^{91}$ Even as the IUM came to be purged of foreign staff, these cross-border connections-cited in biographical materials as evidence of al-Jami's religious credentials - point to the legacy of transactions within a far-reaching transnational economy of migrants, material resources, and spiritual capital which played a role from the start in enabling and legitimizing the operation of its Wahhabi missionary project.

\section{CONCLUSION}

By the time the Wahhabi establishment embarked upon efforts to extend the scope of its reformist mission to new audiences beyond Saudi Arabia from the mid-20th century, its 
scholars had already long been interacting with their counterparts in distant locations. However, the most vigorous of these exchanges had tended to occur with interlocutors who were already committed to expressions of Islam that shared substantial common ground with Wahhabism. The IUM represented a rupture in that its missionary ambitions were far more universal, calling for the problematic task of extending influence to communities who would by no means necessarily be receptive to Wahhabi claims to religious authority. While the availability of petrodollars must certainly figure in any attempt to understand the dynamics that ensued, this is only one part of the picture.

In seeking to understand how Saudi oil wealth fed into the extension and remaking of Wahhabi religious authority in the period in question, I have suggested situating the IUM within a transnational religious economy comprising flows of migrants and the use of evolving social technologies to facilitate transactions in material and symbolic resources. The IUM undoubtedly benefited enormously from the ability to offer comprehensive scholarship packages to its migrant students, as well as from its site in Medina. However, I have argued that it is also significant that material wealth made available by the Saudi state provided for the co-optation of migrant staff from across the Islamic world. These migrants brought with them spiritual capital, including skills, knowledge, and qualifications, in diverse forms that stood to be recognized as legitimate and valuable bases of religious authority with a wide array of constituencies. The bureaucratization of education provided for oversight of these processes by the Wahhabi establishment and also allowed for the institutionalization of these symbolic resources. These transactions, I have suggested, served an important legitimizing function for an initiative that might otherwise have been exceedingly vulnerable to charges of exclusivist parochialism. In highlighting these aspects of the IUM project, the historiography developed here serves to emphasize the extent to which Saudi state-funded Wahhabi missionary work has hinged on multivalent flows of persons and resources, not only outwards from the kingdom but also inwards from locations around the world.

\section{NOTES}

Author's note: I am very grateful to the IJMES reviewers for their detailed, fair, and constructive critique. Others who gave valuable feedback on material that would eventually make its way into this article include John Chalcraft, Neil Ketchley, John Sidel, Madawi Al-Rasheed, James Piscatori, and Matthias Determann. Lamiaa Shehata was kind enough to offer advice on some finer points of translation. I also thank the former students of the Islamic University of Medina who have lent me their time and trust. The research project that gave rise to this article was made possible by generous funding from the London School of Economics and Political Science, the Gerda Henkel Foundation, the University of London Central Research Fund, the Gilchrist Educational Trust, the Abdullah al-Mubarak al-Sabah Foundation, and the British Society for Middle Eastern Studies. The staff at the King Faisal Center for Research and Islamic Studies in Riyadh facilitated visa documents and provided me with office space during a period as a visiting researcher at that institution in 2012 .

1'Abd Allah al-'Aqil, Min A 'lam al-Da'wa wa-l-Haraka al-Islamiyya al-Mu'asira (n.p.: Dar al-Bashir, 2008), 263.

${ }^{2}$ Sa $a$ id ibn Falih al-Maghamisi, "Juhud Khadim al-Haramayn al-Sharifayn fi Ta ${ }^{c}$ lim Abna' al-Muslimin min Khilal al-Minah al-Dirasiyya allati Tuqimuha al-Jami`a al-Islamiyya," Majallat al-Jami ‘a al-Islamiyya bi-l-Madina al-Munawwara 118 (n.d.) (henceforth Majallat al-Jami ${ }^{`} a$ ).

${ }^{3}$ Works addressing this geopolitical and domestic juncture include inter alia Alexei Vassiliev, The History of Saudi Arabia (New York: New York University Press, 2000), chap. 16 and 17; Madawi Al-Rasheed, A History of Saudi Arabia (Cambridge: Cambridge University Press, 2002), chap. 4; and John Chalcraft, 
"Migration and Popular Protest in the Arabian Peninsula and the Gulf in the 1950s and 1960s," International Labor and Working-Class History 79 (2011): 28-47. The emergence of the IUM in this context is also touched upon in Michael Farquhar, "The Islamic University of Medina Since 1961: The Politics of Religious Mission and the Making of a Modern Salafi Pedagogy," in Shaping Global Islamic Discourses: The Role of Al-Azhar, Al-Medina, and Al-Mustafa, ed. Keiko Sakurai and Masooda Bano (Edinburgh: Edinburgh University Press, 2015).

${ }^{4}$ These tropes are pervasive in dozens of articles documenting the founding of the project in local newspapers and journals_including al-Madina al-Munawwara, al-Bilad, al-Nadwa, and al-Manhal-from the late 1950s.

${ }^{5}$ Abdulaziz H. Al-Fahad, "From Exclusivism to Accommodation: Doctrinal and Legal Evolution of Wahhabism," New York University Law Review 79 (2004): 485-519; Joas Wagemakers, "The Enduring Legacy of the Second Saudi State: Quietist and Radical Wahhabi Contestations of al-Wala wa-1-Bara," International Journal of Middle East Studies 44 (2012): 93-110.

${ }^{6}$ Hamadi Redissi, "The Refutation of Wahhabism in Arabic Sources, 1745-1932," in Kingdom without Borders: Saudi Arabia's Political, Religious and Media Frontiers, ed. Madawi Al-Rasheed (New York: Columbia University Press, 2008), 172-77.

${ }^{7}$ Stéphane Lacroix, Awakening Islam: The Politics of Religious Dissent in Contemporary Saudi Arabia (Cambridge, Mass.: Harvard University Press, 2011), 13.

${ }^{8}$ Ibid., 14.

${ }^{9}$ Hafiz Wahbah, Arabian Days (London: Arthur Barker, 1964), 62.

${ }^{10}$ The scholar whom he refers to as Said Ibn Atik is presumably the famous $\mathrm{Sa}^{\mathrm{c} d}$ ibn 'Atiq. For biographies of 'Abd Allah ibn 'Abd al-Latif, Sa'd ibn 'Atiq, and Hamad ibn Faris, see 'Abd al-Rahman ibn 'Abd al-Latif Al al-Shaykh, Mashahir 'Ulama’ Najd wa-Ghayruhum, 2nd ed. (Dar al-Yamama li-1-Bahth wa-1-Tarjama wa-1-Nashr, 1394 H. [1974/5]), 129-41, 323-28, 288-89.

${ }^{11}$ Bradford Verter, "Spiritual Capital: Theorizing Religion with Bourdieu against Bourdieu," Sociological Theory 21 (2003): 150.

${ }^{12}$ Ibid., 159-69.

${ }^{13}$ Ibid., 167-68.

${ }^{14}$ Ibid., 161-62.

${ }^{15}$ Ibid., 158.

${ }^{16}$ Talal Asad, The Idea of an Anthropology of Islam, Occasional Papers Series (Washington, D.C.: Georgetown University, Center for Contemporary Arab Studies, 1986).

${ }^{17}$ Bernard Haykel, "On the Nature of Salafi Thought and Action," in Global Salafism: Islam's New Religious Movement, ed. Roel Meijer (London: Hurst, 2009), 38-39.

${ }^{18}$ The label "Wahhabi" is an exonym generally considered derogatory by those to whom it is applied. I use it here for lack of a better alternative and because of the importance of distinguishing the Wahhabi tradition from the broader Salafi tradition.

${ }^{19}$ Rudolph Peters, "Idjtihad and Taqlid in 18th and 19th Century Islam,” Die Welt Des Islams 20 (1980): 131-45; Frank Vogel, Islamic Law and Legal System: Studies of Saudi Arabia (Leiden: Brill, 2000), chap. 2; Guido Steinberg, "Ecology, Knowledge and Trade in Central Arabia (Najd) during the Nineteenth and Early Twentieth Centuries," in Counter-narratives: History, Contemporary Society, and Politics in Saudi Arabia and Yemen, ed. Madawi Al-Rasheed and Robert Vitalis (Basingstoke: Palgrave Macmillan, 2004), 92-93.

${ }^{20}$ On the corpus of texts which had historically formed the basis of Wahhabi scholarship, see inter alia Steinberg, "Ecology, Knowledge and Trade," 90; and David Dean Commins, The Wahhabi Mission and Saudi Arabia (London: I. B. Tauris, 2005), 123-24.

${ }^{21}$ John O. Voll, "Muhammad Hayya al-Sindi and Muhammad Ibn 'Abd al-Wahhab: An Analysis of an Intellectual Group in Eighteenth-Century Madina," School of Oriental and African Studies, Bulletin 38 (1975): 32-39; Basheer M. Nafi, "A Teacher of Ibn 'Abd al-Wahhab: Muhammad Hayat al-Sindi and the Revival of Ashab al-Hadith's Methodology," Islamic Law and Society 13 (2006): 208-41. Nafi's article is an important rejoinder to those who had previously been more circumspect with regard to the significance of Ibn 'Abd al-Wahhab's encounter with al-Sindi. See Michael Cook, "On the Origins of Wahhabism," Journal of the Royal Asiatic Society (Third Series) 2 (1992): 191-202; and Ahmad Dallal, "The Origins and Objectives of Islamic Revivalist Thought, 1750-1850,” Journal of the American Oriental Society 113 (1993): 341-59.

${ }^{22}$ Commins, The Wahhabi Mission and Saudi Arabia, 42.

${ }^{23}$ Links with the Ahl-i Hadith are discussed in more detail later in this article. 
${ }^{24}$ Redissi, "The Refutation of Wahhabism in Arabic Sources, 1745-1932."

${ }^{25}$ Muhammad ibn 'Abd Allah al-Salman, al-Ta'lim fi 'Ahd al-Malik 'Abd al-'Aziz (Riyadh: al-Amana al-'Amma li-1-Ihtifal bi-Murur Mi’at 'Am ‘ala Ta’sis al-Mamlaka, 1999), 69-70.

${ }^{26} \mathrm{On}$ arrangements for instruction in mosque study circles and the issuing of $i j a \bar{z} a$ qualifications in this context, see ibid., 57-84, 101-18.

${ }^{27} \mathrm{Al}$ al-Shaykh, Mashahir, 323-28.

${ }^{28}$ Salman's list comprises seven Al al-Sheikh scholars (Ibrahim ibn 'Abd al-Latif, 'Abd Allah ibn 'Abd al-Latif, Muhammad ibn 'Abd al-Latif, Salih ibn 'Abd al-'Aziz, 'Umar ibn 'Abd al-Latif, Muhammad ibn Ibrahim, and 'Abd al-Latif ibn Ibrahim), along with Muhammad ibn Ibrahim ibn Mahmud, 'Abd al-'Aziz ibn 'Abd al-Rahman ibn Bishr, and Hamad ibn Faris. See al-Salman, al-Ta'lim, 66-68. I draw on biographies of these scholars available in Al al-Shaykh, Mashahir. It should be noted that the dates of death given by Salman

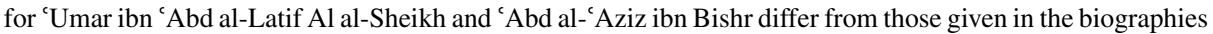
of individuals of the same name in $\mathrm{Al}$ al-Shaykh. It is my assumption that, despite these discrepancies, they are discussing the same two individuals.

${ }^{29}$ Steinberg, "Ecology, Knowledge and Trade," 94. For a list of scholars in Saudi-ruled territories in this period who had traveled for study, see al-Salman, al-Taclim, 85-100.

${ }^{30}$ On those hired to run the Directorate of Education in this period, see 'Ali Muhammad Shalabi, Tarikh al-Ta'lim fi al-Mamlaka al- 'Arabiyya al-Su'udiyya fi 'Ahd Mudiriyyat al-Ma'arif al- 'Amma 1344 H./1926 M.-1373 H./1953 M. (al-Kuwayt: Dar al-Qalam, 1987), 284-89.

${ }^{31}$ Ahmad ibn 'Atiyya al-Ghamidi, ed., al-Kitab al-Watha'iqi 'an al-Jamica al-Islamiyya bi-l-Madina alMunawwara (Medina: al-Jami'a al-Islamiyya, 1998), 212-25. See also Farquhar, "The Islamic University of Medina since 1961."

${ }^{32}$ Farquhar, "The Islamic University of Medina since 1961."

33 "Nizam al-Majlis al-Istishari al-A'la," reproduced in al-Ghamidi, al-Kitab al-Watha'iqi, 147-48.

${ }^{34}$ Ibid., 149-58.

${ }^{35}$ Hamza ibn Hamid ibn Bashir al-Qar'ani, Sullam al-Wusul ila Tarajim 'Ulama’ Madinat al-Rasul (Damascus: Dar al-Ma’mun, 2009), 373-79.

${ }^{36}$ Founding members of the Advisory Council are listed in Dalil al-Jami ${ }^{c}$ a al-Islamiyya fi al-Madina al-Munawwara (Medina: al-Jami'a al-Islamiyya, 1971), 31-32.

${ }^{37}$ Ibid., 45-46, 71-72.

${ }^{38}$ Dalil A'da' Hay'at al-Tadris wa-l-Muhadirin wa-l-Mu'idin (Medina: al-Jami'a al-Islamiyya bi-l-Madina al-Munawwara: Idarat al-Takhtit wa-1-Mizaniyya wa-l-Mutaba'a wa-1-Ahsa', 1402 H. [1981/82]).

${ }^{39}$ Muhammad al-Majdhub, 'Ulama' wa-Mufakkirun 'Araftuhum (Riyadh: Dar al-Shawwaf, 1992), 3:355.

${ }^{40}$ Author's interview with al-Sayyid Nazili, Cairo, 9 November 2011. Al-Sayyid Nazili's role at the IUM is also touched upon in Salah al-Din Hasan, al-Salafiyyun fi Misr (Cairo: Dar Awraq li-1-Nashr, 2012), 90.

${ }^{41}$ Usama Hasan, ed., "In Memoriam-Shaykh 'Abdul Ghaffar Hasan (1330-1427/1913-2007)," Unity (blog), 8 June 2009, accessed 10 June 2013, http://unity1.files.wordpress.com/2009/06/biography-of-shaykhabdul-ghaffar-hasan.pdf.

${ }^{42}$ Author's interviews with Egyptians who had taught at the IUM and in other Saudi Islamic universities, Cairo, April, May, and October 2011.

43،"Akhbar al-Jamica," Majallat al-Jami ‘ 1 (1969); "Akhbar al-Jamica,” Majallat al-Jami a 4 (1972).

${ }^{44}$ 'Abd al-'Aziz al-Qari', "al-Shaykh 'Abd al-Fattah al-Qari'," 'Abd al-'Aziz al-Qari' bi-l-Madina alMunawwara, November 2008, accessed 19 June 2013, http://www.alqary.net/publish/article_282.shtml.

${ }^{45}$ 'Abd al-'Aziz al-Qari', "al-Ta'rif bi-1-Mushrif," 'Abd al- 'Aziz al-Qari' bi-l-Madina al-Munawwara, accessed 19 June 2013, http://www.alqary.net/publish/article_252.shtml.

${ }^{46}$ Al- 'Aqil, Min A 'lam al-Da ${ }^{c} w a, 811-22$; Henri Lauzière, "The Evolution of the Salafiyya in the Twentieth Century through the Life and Thought of Taqi al-Din al-Hilali” (PhD diss., Georgetown University, 2008).

${ }^{47}$ Al-Majdhub, 'Ulama' wa-Mufakkirun, 3:151-64; al-Qar'ani, Sullam al-Wusul, 283-94.

${ }^{48}$ Al-Majdhub, 'Ulama' wa-Mufakkirun, 3:251-60; al- Qar'ani, Sullam al-Wusul, 193-99.

${ }^{49}$ Lacroix, Awakening Islam, 38-42.

${ }^{50}$ One prominent example is the Egyptian Muslim Brother 'Ali Juraysha. Al-Majdhub, 'Ulama' waMufakkirun, 1:155-70.

${ }^{51}$ Ibid., 1:49-61.

${ }^{52}$ Louis Brenner, Controlling Knowledge: Religion, Power, and Schooling in a West African Muslim Society (Bloomington, Ind.: Indiana University Press, 2001), 96-102, 146-49. 
${ }^{53}$ Dalil al-Jami ${ }^{c} a, 127$; al-Ghamidi, al-Kitab al-Watha iqi, 361-66.

${ }^{54}$ 'Abd Allah ibn 'Abd al-Rahman ibn Salih Al Bassam, 'Ulama’ Najd khilal Thamaniyat Qurun (Riyadh: Dar al-'Asima, 1419 H. [1998/99]), 3:275-79; Khalid Mohammad Younus, "The Twentieth Century and the Efforts of Missionary Movements in Egypt” (PhD diss., University of Karachi, 2006), 196-200; Ahmad Muhammad Tahir, Jama 'at Ansar al-Sunna al-Muhammadiya: Nash'atuha, Ahdafuha, Manhajuha, Juhuduha (Cairo: Jama'at Ansar al-Sunna al-Muhammadiya, 2006), 173-84; al-'Aqil, Min A 'lam al-Da'wa, 43543.

${ }^{55}$ They included brothers Muhammad 'Abd al-Wahhab al-Banna and Hasan 'Abd al-Wahhab al-Banna, as well as Sa'd Nida and 'Abd al-Fattah Salama.

${ }^{56} \mathrm{See}$, for example, the biography of 'Abd al-Fattah Salama, "al-Shaykh al-Duktur 'Abd al-Fattah Salama, 1358-1418 H., 1938-1998 M.,” Majallat al-Tawhid 26 (1998), 58-59.

${ }^{57}$ Steinberg, "Ecology, Knowledge and Trade," 94-95; Lacroix, Awakening Islam, 84; and Al al-Shaykh, Mashahir, 323-28.

${ }^{58}$ Dalil al-Jami ‘ $a$, 127; al-Ghamidi, al-Kitab al-Watha 'iqi, 361-66.

${ }^{59}$ Author's interview with an IUM graduate, London, 27 June 2011

${ }^{60}$ Interviews conducted by the author at Dar al-' Ulum, al-Azhar, and elsewhere in Cairo, April, May, and October 2011.

${ }^{61}$ 'Abd Allah ibn Salih al-'Abbud, Juhud al-Mamlaka al-'Arabiyya al-Su'udiyya fi al-Da'wa ila Allah Ta'ala fi al-Kharij min khilal al-Jami ' a al-Islamiyya (al-Madina al-Munawwara: al-Jami`a al-Islamiyya, 2004), 841.

62،Akhbar al-Jami'a,” 1969. See also al-`Abbud, Juhud al-Mamlaka, 840.

${ }^{63}$ Muhammad Qasim Zaman, The Ulama in Contemporary Islam: Custodians of Change (Princeton N.J.: Princeton University Press, 2002), 175.

${ }^{64}$ Ibid.

${ }^{65}$ Gilles Kepel, The War for Muslim Minds: Islam and the West (Cambridge, Mass. and London: Belknap, 2004), chap. 5; and Lacroix, Awakening Islam.

${ }^{66}$ Madawi Al-Rasheed, Contesting the Saudi State: Islamic Voices from a New Generation (Cambridge: Cambridge University Press, 2007).

${ }^{67}$ Farquhar, "The Islamic University of Medina since 1961."

${ }^{68}$ Ibid.

${ }^{69} \mathrm{Ibid}$.

${ }^{70}$ Al-Ghamidi, al-Kitab al-Watha'iqi, 55-56

${ }^{71}$ Al-'Abbud, Juhud al-Mamlaka, 448-663.

${ }^{72}$ Al-Majdhub, 'Ulama’ wa-Mufakkirun, 3:179-91; Al al-Shaykh, Mashahir, 517-20; al- Qar'ani, Sullam al-Wusul, 133-53.

${ }^{73}$ Author's interview with an IUM graduate, London, 24 June 2011. This first part of the Islamic declaration of faith translates as, "There is no God but God."

${ }^{74}$ Al-Majdhub, 'Ulama' wa-Mufakkirun, 1:27-48; Lauzière, "The Evolution of the Salafiyya," 338-39.

${ }^{75}$ Dalil al-Jami ${ }^{`} a, 45-46,71-72$.

${ }^{76}$ Dalil A ${ }^{\mathrm{C}} \mathrm{da} \mathrm{P}^{\mathrm{T}}$ Hay'at al-Tadris.

${ }^{77}$ Ibid.

${ }^{78}$ Donald Malcolm Reid, Cairo University and the Making of Modern Egypt (Cambridge: Cambridge University Press, 1990), 198.

${ }^{79}$ Dalil A'da' Hay'at al-Tadris.

${ }^{80}$ Ibid. Particularly common among migrant staff members were degrees from the Universities of 'Ayn Shams, Alexandria, and Cairo in Egypt, and Khartoum University in Sudan.

${ }^{81}$ Verter, "Spiritual Capital," 160.

${ }^{82}$ Al-Majdhub, 'Ulama' wa-Mufakkirun, 3:179-91.

${ }^{83}$ Author's interviews with Egyptian former employees of Saudi educational institutions and a former student of the IUM, Cairo, March and October 2011. See also Lacroix, Awakening Islam, 47.

${ }^{84}$ Erin Kenny, "Gifting Mecca: Importing Spiritual Capital to West Africa," Mobilities 2 (2007): 363-81.

85 “Akhbar al-Jami 'a," Majallat al-Jami 'a 2 (1969); "Akhbar al-Jami'a," Majallat al-Jami 'a 6 (1973).

${ }^{86}$ Dalil A'da’ Hay'at al-Tadris, 34-44.

${ }^{87}$ Al-Ghamidi, al-Kitab al-Watha'iqi, 277.

${ }^{88}$ Lacroix, Awakening Islam, 211-21. 
${ }^{89}$ Stéphane Lacroix, "Between Revolution and Apoliticism: Nasir al-Din al-Albani and His Impact on the Shaping of Contemporary Salafism," in Global Salafism, 58-80.

${ }^{90}$ Roel Meijer, "Politicising al-jarh wa-l-ta'dīl: Rabic B. Hadi al-Madkhali and the Transnational Battle for Religious Authority," in The Transmission and Dynamics of the Textual Sources of Islam: Essays in Honour of Harald Motzki, ed. Nicolet Boekhoff-Van der Voort, Kees Versteegh, and Joas Wagemakers (Leiden: Brill, 2011), 375-99.

${ }^{91}$ Al-Qarcani, Sullam al-Wusul, 225-35. 